\title{
Cell Surface Receptor
}

National Cancer Institute

\section{Source}

National Cancer Institute. Cell Surface Receptor. NCI Thesaurus. Code C17067.

A receptor protein that is localized to the plasma membrane and may have exposure to the extracellular milieu. 